\title{
CAMA
}

Centre for Applied Macroeconomic Analysis

\section{Commodity Price Volatility, Fiscal Balance and Real Interest Rate}

\section{CAMA Working Paper 79/2020 September 2020}

\section{Monoj Kumar Majumder}

Tasmanian School of Business and Economics, University of Tasmania, Australia

Department of Agricultural Economics, Sher-e-Bangla Agricultural University, Bangladesh

\section{Mala Raghavan}

Tasmanian School of Business and Economics, University of Tasmania, Australia Centre for Applied Macroeconomic Analysis, ANU

\section{Joaquin Vespignani}

Tasmanian School of Business and Economics, University of Tasmania, Australia Centre for Applied Macroeconomic Analysis, ANU

\section{Abstract}

The objective of this study is to explore the impact of commodity price volatility on the governments' fiscal balance. Using a dynamic panel data model for 108 countries from 1993 to 2018, this study finds that governments' fiscal balance deteriorates with commodity price volatility. A one standard deviation increase in commodity price volatility leads to a reduction of approximately 0.04 units in the fiscal balance as a percentage of gross domestic product. In addition, we examine the role of real interest rates in influencing the relationship between commodity price volatility and fiscal balance. The empirical results suggest that the negative impact of commodity price volatility on fiscal balance can be mitigated with lower real interest rate. 


\title{
Keywords
}

Commodity prices, commodity price volatility, fiscal balance, real interest rate

\author{
JEL Classification
}

E58, E62, G01

Address for correspondence:

(E) cama.admin@anu.edu.au

ISSN 2206-0332

The Centre for Applied Macroeconomic Analysis in the Crawford School of Public Policy has been established to build strong links between professional macroeconomists. It provides a forum for quality macroeconomic research and discussion of policy issues between academia, government and the private sector.

The Crawford School of Public Policy is the Australian National University's public policy school, serving and influencing Australia, Asia and the Pacific through advanced policy research, graduate and executive education, and policy impact. 


\title{
Commodity Price Volatility, Fiscal Balance and Real Interest Rate
}

\author{
Monoj Kumar Majumder a,c, Mala Raghavan a,b, Joaquin Vespignani a,b \\ a Tasmanian School of Business and Economics, University of Tasmania, Australia \\ b Centre for Applied Macroeconomic Analysis, Australian National University, Australia \\ c Department of Agricultural Economics, Sher-e-Bangla Agricultural University, Bangladesh
}

\begin{abstract}
The objective of this study is to explore the impact of commodity price volatility on the governments' fiscal balance. Using a dynamic panel data model for 108 countries from 1993 to 2018 , this study finds that governments' fiscal balance deteriorates with commodity price volatility. A one standard deviation increase in commodity price volatility leads to a reduction of approximately 0.04 units in the fiscal balance as a percentage of gross domestic product. In addition, we examine the role of real interest rates in influencing the relationship between commodity price volatility and fiscal balance. The empirical results suggest that the negative impact of commodity price volatility on fiscal balance can be mitigated with lower real interest rate.
\end{abstract}

Keywords: Commodity prices, commodity price volatility, fiscal balance, real interest rate JEL classification: E58, E62, G01

Corresponding authors.

E-mail addresses: monojkumar.majumder@utas.edu.au (M. K. Majumder) mala.raghavan@utas.edu.au (M. Raghavan), Joaquin.vespignani@utas.edu.au (J. Vespignani) 


\section{Introduction}

According to Bellemare, Barrett and Just (2013), Dwyer, Gardner and Williams (2011), Tujula and Wolswijk (2004) and Dehn (2000), commodity price volatility generates uncertainty in the economy, delays stability in government and private budgets, undermines the predictability of economic planning and potentially contributes to lower economic growth. In terms of governments' fiscal positions, commodity-exporting countries generally rely on commodity royalties. Fiscal positions in commodity-importing countries may also be affected, as some countries tax commodity imports heavily. Following the literature, we use fiscal balance as a measure of government's fiscal policy.1

Our study explores the impact of commodity price volatility on fiscal balance for 108 countries in a panel data framework from 1993 to 2018. In addition, this study examines the role of real interest rate in influencing the relationship between commodity price volatility and government's fiscal balance.

Although considerable literature examines the relationship between the macroeconomy and commodity price volatility, there has been little consideration of commodity price volatility on fiscal position.2 This empirical study aims to analyze and quantify the relationship between commodity price volatility and fiscal balance by exploring the following research questions:

(i) How does commodity price volatility affect government's fiscal balance?

(ii) Are these effects different for commodity-exporting and commodity-importing countries?

\footnotetext{
1 See for example: Alley (2016), Spatafora and Samake (2012), Kaminsky (2010), and Tujula and Wolswijk (2004). Fiscal balance is a sound representation of the government's fiscal position because governments express annual targets as a flow term such as, balance or deficit. In this study, we define government's fiscal balance as the ratio between net lending and net borrowing. Fiscal balance improves when net lending increases and or net borrowing decreases. In other words, the measure of fiscal balance is referred to the changes in the stock of government's debt.

2 Among them, Guerineau and Ehrhart (2012) found that commodity price volatility negatively affected tax revenues in the developing countries.
} 
(iii) How do real interest rates affect the nexus between commodity price volatility and fiscal balance?

We first estimate the impact of commodity price volatility on fiscal balance for all 108 countries (see Table A1 for the list of countries included in this study). The sample countries are then divided into two subgroups-commodity-exporting and commodity-importing countries to examine how the impact of commodity price volatility differs according to the level of commodity endowments (see Table A2).3 This study also examines the effect of the 10 most-traded commodities' price volatilities on fiscal balance. 4

We also assess the role of real interest rates in reducing the negative impact of commodity price volatility on fiscal balance. Our hypothesis is that a lower real interest rate helps to reduce the adverse impact of commodity price volatility on fiscal balance. In periods of high commodity price volatility, the Central Bank (CB) can reduce the nominal interest rate to stimulate investments. We hypothesise that under the sticky-price assumption, a reduction in nominal interest rate leads to a reduction in real interest rate in the short-run. Lower interest rate reduces the cost of capital, boosting investment and increasing aggregate demand. Therefore, fiscal position improves as tax base increases. In particular for countries with a progressive tax system.

A dynamic panel data regression model is used in this study to explore the impact of commodity price volatility on fiscal balance.5 This framework has the advantage of reducing

\footnotetext{
3 We select commodity-exporting countries by following Cavalcanti et al (2012), who classified countries as commodity exporters if the primary commodity constitutes more than 50 per cent of the country's total exports. 4 The top 10 traded commodities are crude oil, steel, soybean, iron ore, maize, gold, copper, aluminium, silver and gas.

5 Panel data allows the inclusion of data for $N$ cross-sections and $T$ time periods (Asteriou \& Hall 2015). The combined panel data matrix set consists of a time series for each cross-sectional member in the data set and offer a variety of estimation methods. In this study, we have data for 108 countries and the time period is 26 years. Hence, a panel framework is an appropriate representation for this study.
} 
serial correlation. ${ }^{6}$ Our empirical findings show that fiscal balance deteriorates with commodity price volatility in both the full sample and commodity-exporting countries. However, we do not find any statistically significant effect in commodity-importing countries. The empirical results also show that fiscal balance weakens with an increase in real interest rate. The negative impact of commodity price volatility on fiscal balance also increases with a higher real interest rate. Our results are robust to different econometric estimations such as pooled OLS, fixed effect, random effect and general methods of moments estimations.

This study relates to two strands in the existing literature. First, the literature addresses the nexus between commodity prices and fiscal balance. In the commodity-exporting countries, fiscal balance improves with an increase in commodity prices, as explained by Bleaney and Halland (2016), Murphy et al (2010), Sinnott (2009), Kumah and Matovu (2007) and Böwer et al (2007). Conversely, Spatafora and Samake (2012), Medina (2010) and Kaminsky (2010) argue that fiscal balance deteriorates with increased commodity prices. Here, we explore the impact of commodity price volatility on government's fiscal balance along with commodity price changes.

Second, this study is related to monetary policy literature. A higher real interest rate increases the cost of borrowing, which leads to lower investment (Malawi \& Bader 2010) and higher unemployment (Doğrul \& Soytas 2010) leading to worsening of fiscal balance. For countries under more flexible exchange rate regimes, higher interest rates could also increase the value of their domestic currency (currency appreciation), making domestic exports less competitive in the international market; therefore, government export revenue decreases with interest rate hikes.

\footnotetext{
${ }^{6}$ In our dynamic panel data model (equation 1), the Durbin-Watson (DW) statistic is 2.07 which indicates there is no serial autocorrelation. However, when we exclude the lag dependent variable from the model, the value of the DW statistic is 0.95 which is much lower than the standard value, indicating the presence of serial autocorrelation.
} 
The paper proceeds as follows. Section 2 reviews the literature. The methodology of this study is described in Section 3. We describe the data and variables in Section 4. Section 5 presents the empirical results from panel data estimation. Finally, Section 6 provides the conclusion and directions for future study.

\section{Literature review}

The literature on the impact of commodity prices on fiscal balance is extensive; however, the effect of commodity price volatility remains unexplored. Kumah and Matovu (2007), Bleaney and Halland (2016), Murphy et al (2010), Sinnott (2009), and Böwer et al (2007) find that government's fiscal balance improves in commodity-exporting countries with rising commodity prices.

Céspedes and Velasco (2014) report that fiscal balance improves over time in commodity-exporting countries with higher commodity prices. They find that in the 1970s fiscal balance increased by 0.03 per cent of GDP; in the 2000s, fiscal balance increased by 0.11 per cent of GDP in response to commodity prices rises. On the other hand, Kaminsky (2010) finds evidence that booms in commodity prices do not necessarily lead to larger fiscal surpluses in developing countries. This implies that positive commodity price shocks may lead to strong procyclical fiscal policies in these developing countries, leading a weaker fiscal balance position. She also argues that in OECD countries, fiscal policy is of an acyclical nature. However, according to Keynesian theory and Barro's tax smoothing models, fiscal policy should be countercyclical.7

To explain procyclical behaviour, Talvi and Vegh (2005), Lane (2003), and Tornell and Velasco (2000) describe the concept of 'political distortion', which emerges due to the

\footnotetext{
7 Countercyclical fiscal policy indicates that governments should decrease spending during the 'good times' and increase during 'bad times'. Conversely, pro-cyclical fiscal policy means that governments increase expenditure during 'good times' and decrease during 'bad times'.
} 
'voracity effect'.8 As a result of this effect, government spends more to achieve balance among the sectors of the country. Conversely, Duncan (2014) and Alesina et al (2008) claim that 'political rent' or 'rent-seeking' activities are responsible for the political distortion. During boom times, voters in the commodity-abundant countries demand immediate benefits in the form of public goods or lower tax rates. They fear that corrupt governments may spend extra revenue as 'political rent' or 'rent-seeking'. To fulfill voters' demands, corrupt governments cannot accumulate additional income from a commodity windfall and thus, increase spending to satisfy voters to avoid becoming unpopular and losing power. Frankel (2011) argues that governments start investment in infrastructure and increase the salary of the government employees during the upturns. These studies however only focused on commodity price changes and did not consider commodity price volatility.

Some literature documents the response of fiscal positions to the output cycle rather than directly linking to commodity price cycles, that is, they indirectly link commodity price fluctuations to fiscal outcomes. These studies only examine the impact of commodity prices through their effects on GDP. According to Ilzetzki and Végh (2008), Talvi and Vegh (2005), Kaminsky et al (2004), and Gavin et al. (1996), commodity-exporting countries follow procyclical fiscal policy, especially during periods of low growth. However, this literature does not consider the direct impact of commodity price volatility on fiscal positions.

This study aims to fill the gap in the literature by introducing the impact of commodity price volatility on fiscal position. We argue that commodity price volatility plays an important role in determing the fiscal balance, as commodity price volatility may induce uncertanty on economic growth and budget predictability. We use the most recent data available (up to 2018),

\footnotetext{
8 The voracity effect indicates that there exists a competition for funds among different units of the governments, such as ministries, provinces, et cetera. Governments deviate from the tax-smoothing model and are unable to run surpluses due to political distortions.
} 
which captures the effect of the global financial crisis (GFC) in 2007-2009 and the European debt crisis.

\section{Methodology}

To explore the impact of commodity price volatility on the fiscal balance, this study employs three dynamic panel data estimation models: (i) pooled ordinary least square (pooled OLS); (ii) fixed-effect (FE) and (iii) random effect (RE) models, which are commonly used in the literature.9

\subsection{The benckmark model}

Our benchmark model essentially captures all effects that are specific to a country and that they do not vary over time (fixed effect), meaning that the model controls for unobserved heterogeneity when it remains constant over time and is correlated with all dependent and independent variables. This model selection is supported by the Hausman test (see Section 4 and Table A6).

We estimate the following model:

$$
\begin{aligned}
& F B_{i, t}=\beta_{0 i}+\beta_{1} F B_{i, t-1}+\beta_{2} C P V_{i, t}+\beta_{3} P C C P_{i, t}+\beta_{4} C A P_{i, t}+\beta_{5} M I_{i, t}+\beta_{6} R I R_{i, t} \\
& +\beta_{7} R I R_{i, t} * C P V_{i, t}+\varepsilon_{i, t}
\end{aligned}
$$

Where $\beta_{0 i}$ is the unobserved time-invariant individual effect. $F B_{i, t}$ is the fiscal balance (percent of GDP) whereas $F B_{i, t-1}$ represents the lag in fiscal balance (percent of GDP). $C P V_{i, t}$ represents commodity price volatility and $P C C P_{i, t}$ indicates the percentage change in commodity prices. $C A P_{i, t}$ represent capital growth (annual percent), whereas, $M I_{i, t}$ and $R I R_{i, t}$ indicate military expense (percent of GDP) and real interest rate (annual percent), respectively.

9 We do not use period fixed effect models, period random effect models and combine effects (both cross-section and period fixed) models because commodity price data is fixed in cross-section levels. 
Comprehensive descriptions of the data and details about the sources of all variables are presented in Table A3 in Appendix A.

The subscripts $i$ and $t$ denote the country and time period, respectively. The idiosyncratic disturbance term is denoted by $\varepsilon_{i, t}$. By using lag dependent variable, we capture the autocorrelation in the model. In this study, we also include an interaction term in equation (1), denoted by $R I R_{i, t} * C P V_{i, t}$, to examine the hypothesis that a lower real interest rate reduces the negative impact of commodity price volatility on fiscal balance.

Using equation (1), we use estimates for the different groups of countries-(i) full sample, (ii) commodity-exporting and (iii) commodity-importing countries - to examine the hypothesis that the impact of commodity price volatility differs with the level of commodity endowments. By using equation (1), we also examine the impact of the 10 most-traded commodities to test the hypothesis that the price volatility of various commodities affects fiscal balance differently.

\section{Data and description of the variables}

\subsection{The data}

We use unbalanced annual panel data for 108 countries for the period 1993 to 2018 . The countries and periods included are selected based on data availability from the World Bank (WB) and the International Monetary Fund (IMF).The data for fiscal balance are collected from the World Economic Outlook (WEO), IMF. Other variables such as capital growth, military expenses, and real interest rates are obtained from the World Development Indicator (WDI), WB.

Data for commodity prices are obtained from the IMF primary commodity price data portal. We convert the data into the annual form by taking the average of monthly data. Commodity prices are expressed as an index using a 2016 base year, including both fuel and 
non-fuel price indices. The data for 10 most-traded commodities are collected from the same source. We estimate commodity price volatility from monthly commodity price index to capture monthly price variation using standard deviation. 10 This overcomes the potential problem that the volatility occurs in the middle of the year such that the variation is hidden in the annual data.

Following Mondal and Khanam (2018), Arezki et al. (2014), and Aghion et al. (2009) this study uses standard deviation as a measure of the volatility of commodity price. The advantage of this method is its simplicity: it does not depend on the unit of measurement. Mathematically, commodity price volatility for each year is calculated by using standard deviation,

$$
\sigma_{t}=\sqrt{\sum_{\tau=1}^{12} \frac{\left(P_{\tau}-\mu_{t}\right)^{2}}{12-1}}
$$

where, $\sigma_{\mathrm{t}}=$ commodity prices volatility at time $t, P_{\tau}=$ observed monthly prices, $\mu_{\mathrm{t}}=$ average price $\left(\mu_{t}=(1 / 12) \sum_{\tau=1}^{12} P_{\tau}\right)$, and $\tau=$ months $(1,2,3 \ldots 12)$

Figure 1 shows a significant spike in commodity price volatility during the GFC period of 2007-2009. We also observe that in the pre-GFC periods (i.e., from the early-1990s to the mid-2000s), commodity price volatility was low, reflecting to a period referred as the 'Great Moderation'.11

\subsection{Unit root test, descriptive statistics and Hausman test}

Tables A4 present the descriptive statistics. This Table show that there is a significant difference between the maximum and minimum values of the commodity price volatility which

\footnotetext{
10 For example, with monthly data, the commodity price volatility in 2018 is computed as the commodity price volatility over the data from 2018:1 to 2018:12.

11 "Great Moderation" refers to a reduction in the volatility of business cycle fluctuations starting in the mid1980s. Bernanke (2004) hypothesize three potential causes for this economic stability: structural change in the economy, improved economic policy and good luck.
} 
are 30.37 and 0.99 , respectively. The standard deviation of commodity price volatility is 6.20 indicating that there is a large dispersion from its mean value (7.25).

In Table A5, we use the Augmented Ducky-Fuller (ADF) and the Phillips-Perron (PP) tests to evaluate the stationary properties of all variables. The stationary variable is characterised by having a constant mean and variance over time, and the covariance between two values in the series depends on the length of time between the two values, but not on the actual times when the value is observed. Apart from commodity prices, all other variables included in the model are stationary at $\rho=0.05$. However, the $\rho$-value of commodity prices is greater than 0.05 , indicating that it is not stationary. To make this series stationary, we use the percentage change of the series.

We calculate the percentage change in commodity price as follows:

$$
P C C P_{t}=\frac{P_{t 2}-P_{t 1}}{P_{t 1}} X 100
$$

Where $P C C P_{t}=$ percentage change in commodity price, $P_{t 1}=$ commodity prices at time $t_{1}$ and $P_{t 2}=$ commodity prices at time $t_{2}$.

Table A6, shows that the $p$-value of the Hausman test is less than $5 \%$, indicating that we can reject the null hypothesis and accept the alternative hypothesis that the FE model is appropriate, this result is consistent for all three country groups.

\section{Results and discussion}

In this section, we describe all empirical results estimated by our benchmark model (FE) for all countries in the sample, and for commodity-exporting and commodity-importing countries. 


\subsection{Results for different country groups (full sample, commodity-exporting and commodity-importing countries)}

Table 1 shows the results of the estimation of Equation 1 for all the countries in the sample. Columns 1, 2 and 3 in Table 1 represent the pooled OLS, FE and RE models, respectively. As shown in column 2 , the coefficient on the commodity price volatility is negative $(-0.04)$ that a one standard deviation increase in commodity price volatility is associated with a fall in fiscal balance as a share of GDP of over 0.04 units. The results are consistent across all three panel data estimation models (columns 1-3) and are statistically significant at the 1 percent level.

The positive coefficient of commodity prices is 0.04 , which indicates that governments' fiscal balance improves with rising commodity prices. A one-unit increase in commodity prices changes is associated with a improvement in fiscal balance of 0.04 units (see Table 1, column 2). This implies that governments do accrue additional revenues from a commodity prices windfall. The results are consistent across all three panel data estimation models and are statistically significant at the 1 percent level.

The positive coefficient of capital formation indicates that fiscal balance improves with an increase of the capital growth. This result is consistent with the view of Milesi-Ferretti and Moriyama (2006) that capital growth contributes to economic growth and prosperity, which increases investment and employment as well as fiscal balance. The negative coefficient of military expense indicates that fiscal balance deteriorates with the increase of military expenses. This result is in line with Cappelen et al (1984) who find that Government expenditure increases with the increase of military expenses, leading to higher tax rates in the private sector, which reduce private investment and eventually deteriorate the fiscal balance.

The negative coefficient of the real interest rate indicates that fiscal balance deteriorates with an increase of the real interest rate. This result is consistent with the view of Comley et al 
(2002) that a higher real interest rate causes lower capital stock and lower output due to reduced investment levels, resulting in lower fiscal balance. The coefficient of the interaction term between commodity price volatility and real interest rate is -0.004 , this indicate that over our sample $10 \%$ of the negative impact of commodity price volatility on fiscal balance can be mitigated with lower real interest rates. These results are statistically significant at the 1 percent level and consistent with all three models.

Table 2 shows results for the determinants of fiscal balance in the commodity-exporting and commodity-importing countries with pooled OLS, FE and RE models. The estimated coefficient for commodity price volatility is -0.07 in commodity-exporting countries (see column 2), which is higher than the full sample, indicating that commodity price volatility has a larger impact in commodity-exporting countries' fiscal balance. While these results are statistically significant at the 1 percent level for commodity-exporting countries, those for commodity-importing countries are statistically insignificant (see columns 4, 5 and 6).

Table 2 also shows a positive relationship between change in commodity prices and fiscal balance, indicating that fiscal balance significantly improves with increases in commodity prices in commodity-exporting countries (see columns 1, 2 and 3). Exporting countries may accrue more revenues from commodity price booms. Our results also show that fiscal balance improves with the increase in commodity prices in commodity-importing countries (coulns 4, 5, and 6). This result contradicts the twin-deficit hypothesis, which states that current account deficits cause fiscal deficits.12 One of the plausible reasons for this positive link between commodity price changes and fiscal balance is that importing countries collect more revenue by imposing taxes on commodities. For example, in the Organisation for 12 See, e.g., Mohanty (2018), Kalou and Paleologou (2012), Kouassi et al (2004). 
Economic Co-operation and Development (OECD) countries, the average oil import tax is 51.3 percent.

Table 2 shows that the negative impact of commodity price volatility on fiscal balance improves with lower real interest rates in both commodity-exporting and commodity-importing countries (columns 2 and 4) though the size of the negative coefficient is higher in commodityexporting countries. One of the plausible reasons is that, commodity-exporting countries require a large amount of capital to extract commodities (e.g., oil, gas, metals). Therefore, a higher real interest rate increases the cost of borrowing, which reduces; capital growth, investment and output. Consequently, government revenue and fiscal balance decrease with higher real interest rates.

Overall, government fiscal balance deteriorates with the increase in commodity price volatility in all countries in the sample and is stronger for commodity-exporting countries. However, this impact is not statistically significant in commodity-importing countries. The results also confirm that lower real interest rates decrease the adverse effect of commodity price volatility on fiscal balance.

\subsection{Results for disaggregated commodities}

In this section, we discuss the impact of the 10 most-traded commodities' price volatilities on fiscal balance for the same set of countries. Tables 3, 4 and 5 present the empirical results for the full sample, commodity-exporting and commodity-importing countries, respectively.

With few exceptions (i.e., maize, aluminium, copper and gas) the coefficients of all others commodities' price volatilities are statistically significant and negative for the full sample (see Table 3). The estimated coefficient is larger in the case of metal commodities than energy and food commodity groups. One plausible reason for this is that metal price fluctuations over the last 150 years are characterised by three major super-cycles, which lasted 
between 20 and 70 years and the fourth super cycle is assumed to be underway (see Jerrett and Cuddington (2008)).

Among the energy prices, we find that the coefficient of oil price volatility is negative and statistically significant. Oil is considered a vital input in the production process and its price is more volatile than that of any other energy commodity (Rafiq et al 2009). Regnier (2007) estimates that the crude oil price is 95 percent more volatile than other energy commodities because of its global demand and supply equilibrium. Among the food commodities, soybean price volatility is negative and statistically significant. One probable reason is that soybean is used to make diverse food (e.g., soybean oil and meat and dairy substitutes, including tofu and soy milk) and agricultural items (animal feed and biodiesel).

In Table 3, the interaction term is negative and statistically significant in the case of oil, steel, soybean, iron ore, silver, aluminium, coper and gas, indicating that a higher real interest rate increases the negative impact of these commodities' price volatility on fiscal balance. A higher interest rate increases the cost of capital, which deteriorates the fiscal balance. For different primary commodities, investment requirements are different; for some, a large amount of capital and/or longer-term investments are required. For example, the investment time horizon for the oil industry is 5-7 years. Thus, with lower interest rate, investors may increase revenue and pay more taxes improving the fiscal balance.

Table 4 shows a similar pattern of results in commodity-exporting countries, except in the case of steel, iron ore, silver and soybean, where the coefficients are larger than those of the full sample. In the case of other commodities, the size of the coefficient is very similar. Table 5 illustrates that some metal commodities' (steel, and iron ore) price volatilities have a statistically significant effect on fiscal balance. 
From the above discussion, we can conclude that among the disaggregated commodities, the most-traded commodities' price volatilities have a statistically significant negative impact on fiscal balance. For example, metal's price volatility has a larger impact compared to other commodities.

\subsection{Marginal effect}

Marginal effect estimation provides a sound estimate of the degree of change in the dependent variable that will be produced by variation in the independent variables. In this study, we compute the marginal effect of commodity price volatility on fiscal balance in terms of real interest rates. Based on the estimates in Table 1 (full commodity index), we estimate:

$$
\frac{d\left(F B_{i, t}\right)}{d\left(C P V_{i, t}\right)}=-0.04-0.004(\text { Real interest rate })
$$

From equation 4, we can see that the marginal effect of commodity price volatility on fiscal balance is a decreasing function of real interest rate. Figures $2 \mathrm{a}-\mathrm{c}$ plot the marginal effect,

$\frac{d\left(F B_{i, t}\right)}{d\left(C P V_{i, t}\right)}$, on the $\mathrm{Y}$-axis and real interest rates on the $\mathrm{X}$-axis. From figure 2a, we can observe that the marginal effect of commodity price volatility on fiscal balance becomes negative with the increase of real interest rate in full sample that supports our empirical findings in Table 1. Figures $2 b$ and $2 c$ also support our empirical findings in Table 2 that the marginal effect of commodity price volatility on fiscal balance becomes negative with the increase of real interest rate in commodity-exporting and commodity-importing countries, respectively.

\subsection{The general method of moments}

To check the robustness of the results, we use the one-step system General Method of Moments (system-GMM) estimator of Arellano and Bond (1991) and Blundell and Bond (1998) in the estimation that address the problem of endogeneity in the model. Table 6 shows the results of the estimation of Equation (1) using one-step system GMM. From Table 6, we can observe that 
the coefficients of commodity price volatility are $-0.04,-0.07$ and -0.02 in the full sample, commodity-exporting and commodity-importing countries, respectively which are very much similar with our basic FE model findings (presented in Tables 1 and 2). The coefficients of other variables are not significantly altered by the one-step system GMM model from the findings estimated by the benchmark FE model.

\section{Conclusion}

This study explores the impact of commodity price volatility on fiscal balance. To understand its effect, a dynamic panel data regression model is estimated for 108 countries for the period from 1993 to 2018 . Our empirical findings show that commodity price volatility has a negative and statistically significant effect on fiscal balance in the full sample and commodity-exporting countries. However, we do not find any statistically significant impact on commodityimporting countries.

This study also investigates the role of real interest rates in influencing the relationship between commodity price volatility and fiscal balance. Our empirical results show that in our sample the negative impact of commodity price volatility is mitigated by lower real interest rates by 10 percent. A higher real interest rate increases the cost of borrowing, which decreases investment. Based on our empirical findings, we conclude that the adoption of a lower real interest rate will help to reduce the adverse effects of commodity price volatility on fiscal balance. Our results are robust to different econometric estimations such as pooled OLS, fixed effect, random effect and general methods of moments estimations. 


\section{References}

Aghion, P, Bacchetta, P, Ranciere, R \& Rogoff, K 2009, 'Exchange rate volatility and productivity growth: The role of financial development', Journal of Monetary Economics, vol. 56, pp. 494-513.

Alesina, A, Campante, FR \& Tabellini, G 2008, 'Why is fiscal policy often procyclical?', Journal of the European Economic Association, vol. 6, pp. 1006-1036.

Alley, I 2016, 'Oil price volatility and fiscal policies in oil - exporting countries', OPEC Energy Review, vol. 40, pp. 192-211.

Arellano, M., Bond, S., 1991, 'Some tests of specification for panel data: monte carlo evidence and an application to employment equations' Review of Economic Studies 58, 277-297.

Arezki, R, Dumitrescu, E, Freytag, A \& Quintyn, M 2014, 'Commodity prices and exchange rate volatility: lessons from South Africa's capiatl account liberalization, Energy Markets review, vol.19, pp.96-105.

Asteriou, D \& Hall, SG 2015, Applied Econometrics, Palgrave Macmillan, London.

Bernanke, B 2004, The great moderation, speech given at the Meeting of the Eastern Economic Association, 20 February, 2004, Washington, DC.

Bleaney, M \& Halland, H 2016, 'Do resource-rich countries suffer from a lack of fiscal discipline?', Policy Research Working Paper No. 7552, World Bank, Washington, DC.

Bellemare, MF, Barrett, CB \& Just, DR 2013, 'The welfare impacts of commodity price volatility: evidence from rural Ethiopia', American Journal of Agricultural Economics, vol. 95, pp. 877-899.

Blundell, R \& Bond, S., 1998, 'Initial conditions and moment restrictions in dynamic paneldata models' Journal of Econometrics 87, 115-143.

Böwer, U, Geis, A \& Winkler, A 2007, Commodity price fluctuations and their impact on monetary and fiscal policies in Western and Central Africa, European central bank, Frankfurt.

Cappelen, Å, Gleditsch, NP \& Bjerkholt, O 1984, 'Military spending and economic growth in the OECD countries', Journal of Peace Research, vol. 21, pp. 361-373.

Cavalcanti, TVV, Mohaddes, K, \& Raissi, M 2012, Commodity price volatility and the sources of growth, International Monetary Fund, Washington, DC.

Céspedes, LF \& Velasco, A 2014, 'Was this time different?: Fiscal policy in commodity republics', Journal of Development Economics, vol. 106, pp. 92-106.

Comley, B, Anthony, S \& Ferguson, B 2002, 'The effectiveness of fiscal policy in AustraliaSelected issues', Impact of Fiscal Policy Conference, p. 231.

Cuddington, J. T., Ludema, R. \& Jayasuriya, S. A. 2002. Prebisch-Singer Redux, Central Bank of Chile.

Dehn, J 2000 'Commodity price uncertainty in developing countries', <https://core.ac.uk/download/pdf/6280469.pdf>.

Doğrul, HG \& Soytas, U 2010, 'Relationship between oil prices, interest rate, and unemployment: Evidence from an emerging market', Energy Economics, vol. 32, pp. 15231528 .

Duncan, R 2014, 'Institutional quality, the cyclicality of monetary policy and macroeconomic volatility', Journal of Macroeconomics, vol. 39, pp. 113-155. 
Dwyer, A, Gardner, G \& Williams, T 2011, 'Global commodity markets-price volatility and financialisation', RBA Bulletin, June, pp. 49-57.

Frankel, JA 2011, 'How can commodity exporters make fiscal and monetary policy less procyclical?' HKS Faculty Research Working Paper Series RWP11-015, John F. Kennedy School of Government, Harvard University, Boston, USA.

Gavin, M, Hausmann, R, Perotti, R \& Talvi, E 1996, 'Managing fiscal policy in Latin America and the Caribbean: Volatility, procyclicality, and limited creditworthiness', IDB Working Paper No. 269.

Guerineau, S \& Ehrhart, H 2012, 'The impact of high and volatile commodity prices on public finances: Evidence from developing countries', HAL working paper series.

\section{https://halshs.archives-ouvertes.fr/halshs-00659100/document}

Jerrett, D \& Cuddington, JT 2008, 'Broadening the statistical search for metal price super cycles to steel and related metals', Resources Policy, vol. 33, pp. 188-195.

Ilzetzki, E \& Végh, CA 2008, 'Procyclical fiscal policy in developing countries: Truth or fiction?', NBER Working Paper No. 14191, National Bureau of Economic Research, Inc., Cambridge, MA, USA.

International Monetary Fund 2019, Commodity data portal, viwed 2019 <https://www.imf.org/en/Research/commodity-prices>.

Kalou, S and Paleologou, SM 2012, 'The twin deficit hypothesis: revisiting an EMU country', Journal of policy modelling, vol.34, pp.230-241.

Kaminsky, GL 2010, 'Terms of trade shocks and fiscal cycles', National Bureau of Economic Research, Inc., Cambridge, MA, USA.

Kaminsky, GL, Reinhart, CM \& Végh, CA 2004, 'When it rains, it pours: procyclical capital flows and macroeconomic policies', NBER Macroeconomics Annual, vol. 19, pp. 11--53.

Kouassi, E, Mougoue, M and Kymn, K.O 2004, 'Causality tests of the relationtion between twin deficits', Empitical Economics, vol.29, pp.503-525.

Kumah, FY \& Matovu, JM 2007, 'Commodity Price Shocks and the Odds on Fiscal Performance: A Structural Vector Autoregression Approach', IMF Staff Papers, vol. 54, pp. 91-112.

Malawi, AI \& Bader, M 2010, 'The impact of interest rate on investment in Jordan: a cointegration analysis', Journal of King Abdulaziz University: Economics and Administration, vol. 105, pp. 1-26.

Lane, PR 2003, 'The cyclical behaviour of fiscal policy: evidence from the OECD', Journal of Public Economics, vol. 87, pp. 2661-2675.

Medina, L 2010, 'The dynamic effects of commodity prices on fiscal performance in Latin America', International Monetary Fund, Washington, DC.

Milesi-Ferretti, GM \& Moriyama, K 2006, 'Fiscal adjustment in EU countries: A balance sheet approach', Journal of Banking \& Finance, vol. 30, pp. 3281-3298.

Mohanty, R.K. 2018, 'An empirical investigation of twin deficits hypothesis: evidence from India', Journal of Quantitative Economics, vol. 17, pp.579-601. 
Mondal, RK \& Khanam, R 2018, 'The impact of international migrants' remittances on household consumption volatility in developing countries', Economic Analysis and Policy, vol.59, pp. 171-187.

Murphy, PL, Villafuerte, M \& Ossowski, R 2010, Riding the roller coaster: Fiscal policies of nonrenewable resource exporters in Latin America and the Caribbean, International Monetary Fund, Washington, DC.

Omojolaibi, JA \& Egwaikhide, FO 2014, 'Oil price volatility, fiscal policy and economic growth: a panel vector autoregressive (PVAR) analysis of some selected oil-exporting African countries', OPEC Energy Review, vol. 38, pp. 127-148.

Prebisch, R 1962, 'The economic development of Latin America and its principal problems', Economic Bulletin for Latin America.

Rafiq, S, Salim, R \& Bloch, H 2009, 'Impact of crude oil price volatility on economic activities: An empirical investigation in the Thai economy', Resources Policy, vol. 34, pp. 121--132.

Regnier, E 2007, 'Oil and energy price volatility', Energy Economics, vol. 29, pp. 405-427.

Sinnott, E 2009, 'Commodity prices and fiscal policy in Latin America and the Caribbean', Workshop on Myths and Realities of Commodity Dependence: Policy Challenges and Opportunities for Latin America and the Caribbean, World Bank, pp. 17-18

Spatafora, N \& Samake, I 2012, Commodity price shocks and fiscal outcomes.

Talvi, E \& Vegh, CA 2005, 'Tax base variability and procyclical fiscal policy in developing countries', Journal of Development Economics, vol. 78, pp. 156-190.

Tornell, A \& Velasco, A 2000, 'Fixed versus flexible exchange rates: Which provides more fiscal discipline?' Journal of Monetary Economics, vol. 45, pp. 399-436.

Tujula, M \& Wolswijk, G 2004, What determines fiscal balances? An empirical investigation in determinants of changes in OECD budget balances.

World Bank 2019, World Development Indicators, viewed September 2019, < https://data.worldbank.org/indicator/NY.GDP.MKTP.KD>. 
Table 1: Determinants of fiscal balance (full sample)

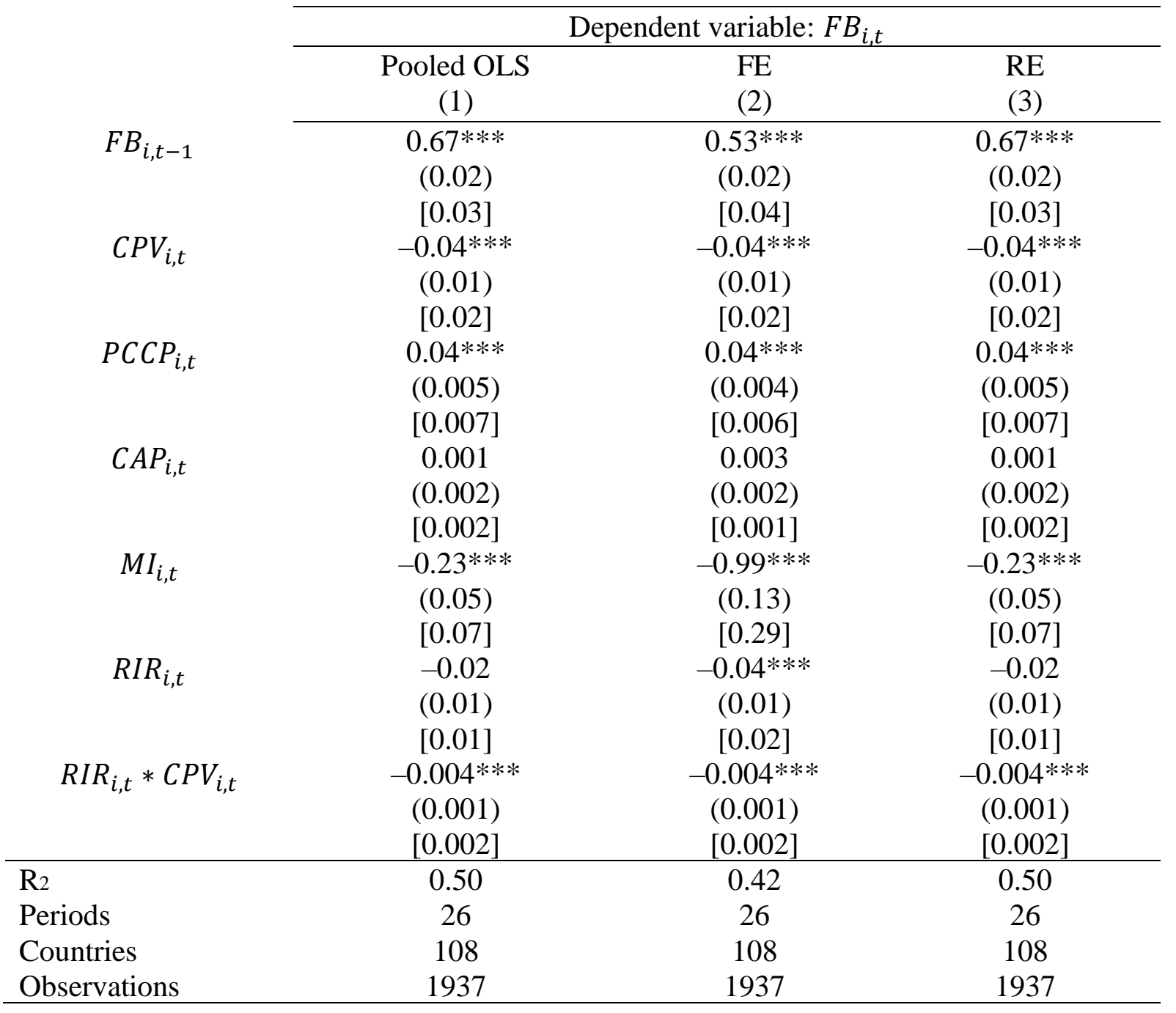

Note: Standard errors are presented below the corresponding coefficients in brackets. The asterisks $* * *, * *$ and $*$ indicate the significance at the 1,5 and 10 percent level, respectively. Cluster standard errors are presented in square brackets. 
Table 2: Determinants of fiscal balance (commodity exporting and importing countries)

\begin{tabular}{|c|c|c|c|c|c|c|}
\hline & \multicolumn{6}{|c|}{ Dependent variable: $F B_{i, t}$} \\
\hline & \multicolumn{3}{|c|}{ Commodity-exporting countries } & \multicolumn{3}{|c|}{ Commodity-importing countries } \\
\hline & $\begin{array}{l}\text { Pooled OLS } \\
\text { (1) }\end{array}$ & $\begin{array}{l}\text { FE } \\
\text { (2) }\end{array}$ & $\begin{array}{l}\mathrm{RE} \\
\text { (3) }\end{array}$ & $\begin{array}{c}\text { Pooled OLS } \\
\text { (4) }\end{array}$ & $\begin{array}{l}\mathrm{FE} \\
(5)\end{array}$ & $\begin{array}{l}\mathrm{RE} \\
(6)\end{array}$ \\
\hline \multirow[t]{3}{*}{$F B_{i, t-1}$} & $0.68 * * *$ & $0.55 * * *$ & $0.68 * * *$ & $0.67 * * *$ & $0.51 * * *$ & $0.67 * * *$ \\
\hline & $(0.02)$ & $(0.03)$ & $(0.02)$ & $(0.02)$ & $(0.02)$ & $(0.02)$ \\
\hline & {$[0.06]$} & [0.09] & {$[0.06]$} & {$[0.004]$} & [0.004] & {$[0.004]$} \\
\hline \multirow{3}{*}{$C P V_{i, t}$} & $-0.08 * * *$ & $-0.07 * * *$ & $-0.08 * * *$ & -0.02 & -0.02 & -0.02 \\
\hline & $(0.02)$ & $(0.02)$ & $(0.02)$ & $(0.02)$ & $(0.02)$ & $(0.02)$ \\
\hline & {$[0.02]$} & {$[0.02]$} & {$[0.02]$} & {$[0.02]$} & {$[0.02]$} & {$[0.02]$} \\
\hline \multirow{3}{*}{$P C C P_{i, t}$} & $0.05 * * *$ & $0.04 * * *$ & $0.05 * * *$ & $0.04 * * *$ & $0.03 * * *$ & $0.04 * * *$ \\
\hline & $(0.006)$ & $(0.006)$ & $(0.006)$ & $(0.006)$ & $(0.006)$ & $(0.006)$ \\
\hline & {$[0.008]$} & {$[0.007]$} & {$[0.0006]$} & {$[0.01]$} & {$[0.008]$} & {$[0.01]$} \\
\hline \multirow[t]{3}{*}{$C A P_{i, t}$} & 0.0007 & 0.001 & 0.0007 & 0.003 & 0.009 & 0.003 \\
\hline & $(0.002)$ & $(0.002)$ & $(0.002)$ & (0.006) & $(0.006)$ & $(0.006)$ \\
\hline & {$[0.001]$} & {$[0.001]$} & {$[0.001]$} & [0.007] & {$[0.005]$} & [0.007] \\
\hline \multirow[t]{3}{*}{$M I_{i, t}$} & $-0.33 * * *$ & $-1.03 * * *$ & $-0.33 * * *$ & $-0.20 * * *$ & $-0.97 * * *$ & $-0.20 * * *$ \\
\hline & $(0.09)$ & $(0.20)$ & $(0.09)$ & $(0.06)$ & $(0.17)$ & $(0.06)$ \\
\hline & {$[0.12]$} & [0.32] & {$[0.12]$} & [0.09] & [0.41] & {$[0.09]$} \\
\hline \multirow[t]{3}{*}{$R I R_{i, t}$} & -0.03 & $-0.03^{*}$ & -0.03 & -0.01 & $-0.05 * * *$ & -0.01 \\
\hline & $(0.02)$ & $(0.02)$ & $(0.02)$ & $(0.02)$ & $(0.02)$ & $(0.02)$ \\
\hline & {$[0.02]$} & {$[0.02]$} & {$[0.02]$} & {$[0.02]$} & {$[0.03]$} & {$[0.02]$} \\
\hline \multirow{3}{*}{$R I R_{i, t} * C P V_{i, t}$} & -0.003 & $-0.005^{* *}$ & -0.003 & $-0.004 * *$ & $-0.003^{*}$ & $-0.004 * *$ \\
\hline & $(0.002)$ & $(0.002)$ & $(0.002)$ & $(0.002)$ & $(0.002)$ & $(0.002)$ \\
\hline & {$[0.003]$} & {$[0.003]$} & {$[0.003]$} & {$[0.002]$} & [0.002] & {$[0.003]$} \\
\hline $\mathrm{R}_{2}$ & 0.54 & 0.48 & 0.54 & 0.48 & 0.38 & 0.48 \\
\hline Periods & 26 & 26 & 26 & 26 & 26 & 26 \\
\hline Countries & 45 & 45 & 45 & 63 & 63 & 63 \\
\hline Observations & 806 & 806 & 806 & 1131 & 1131 & 1131 \\
\hline
\end{tabular}

Note: Standard errors are presented below the corresponding coefficients in brackets. The asterisks $* * *, * *$ and $*$ indicate the significance at the 1,5 and 10 percent level, respectively. Cluster standard errors are presented in square brackets. 
Table 3: Determinants of fiscal balance (full sample)

\begin{tabular}{|c|c|c|c|c|c|c|c|c|c|c|}
\hline & \multicolumn{10}{|c|}{ Dependent variable: $F B_{i, t}$} \\
\hline & $\begin{array}{c}\text { Crude oil } \\
(1)\end{array}$ & $\begin{array}{l}\text { Steel } \\
(2)\end{array}$ & $\begin{array}{c}\text { Soybean } \\
(3)\end{array}$ & $\begin{array}{c}\text { Iron ore } \\
(4)\end{array}$ & $\begin{array}{l}\text { Maize } \\
(5)\end{array}$ & $\begin{array}{c}\text { Gold } \\
(6)\end{array}$ & $\begin{array}{c}\text { Copper } \\
(7)\end{array}$ & $\begin{array}{c}\text { Aluminium } \\
(8)\end{array}$ & $\begin{array}{c}\text { Silver } \\
(9)\end{array}$ & $\begin{array}{l}\text { Gas } \\
(10) \\
\end{array}$ \\
\hline \multirow[t]{3}{*}{$F B_{i, t-1}$} & $0.56^{* * *}$ & $0.47 * * *$ & $0.54 * * *$ & $0.52 * * *$ & $0.55^{* * *}$ & $0.54 * * *$ & $0.57 * * *$ & $0.57 * * *$ & $0.54 * * *$ & $0.52 * * *$ \\
\hline & $(0.02)$ & $(0.02)$ & $(0.02)$ & $(0.02)$ & $(0.02)$ & $(0.02)$ & $(0.02)$ & $(0.02)$ & $(0.02)$ & $(0.02)$ \\
\hline & [0.04] & {$[0.04]$} & [0.04] & {$[0.04]$} & {$[0.04]$} & [0.04] & [0.04] & {$[0.04]$} & {$[0.04]$} & {$[0.04]$} \\
\hline \multirow{3}{*}{$C P V_{i, t}$} & $-0.02 * * *$ & $-0.10 * * *$ & $-0.02 * * *$ & $-0.08 * * *$ & -0.007 & $-0.008 * * *$ & -0.0002 & 0.0001 & $-0.26 * * *$ & 0.003 \\
\hline & $(0.006)$ & $(0.02)$ & $(0.005)$ & $(0.01)$ & $(0.0007)$ & $(0.002)$ & $(0.0002)$ & $(0.0008)$ & $(0.07)$ & $(0.008)$ \\
\hline & {$[0.007]$} & {$[0.02]$} & {$[0.006]$} & {$[0.02]$} & {$[0.007]$} & {$[0.003]$} & {$[0.0002]$} & {$[0.001]$} & {$[0.10]$} & {$[0.01]$} \\
\hline \multirow[t]{3}{*}{$P C C P_{i, t}$} & $0.02 * * *$ & $0.03 * * *$ & $0.02 * * *$ & 0.004 & $0.02 * * *$ & $0.02 * * *$ & $0.03 * * *$ & $0.03 * * *$ & $0.01 * * *$ & $0.02 * * *$ \\
\hline & $(0.003)$ & $(0.005)$ & $(0.004)$ & $(0.002)$ & $(0.004)$ & $(0.005)$ & $(0.003)$ & $(0.004)$ & $(0.003)$ & $(0.003)$ \\
\hline & {$[0.004]$} & {$[0.005]$} & {$[0.005]$} & {$[0.002]$} & {$[0.003]$} & {$[0.005]$} & {$[0.004]$} & {$[0.004]$} & {$[0.003]$} & {$[0.003]$} \\
\hline \multirow[t]{3}{*}{$C A P_{i, t}$} & 0.002 & 0.002 & 0.004 & 0.003 & 0.004 & 0.003 & 0.002 & 0.003 & 0.003 & 0.003 \\
\hline & $(0.002)$ & $(0.002)$ & $(0.002)$ & $(0.002)$ & $(0.002)$ & $(0.002)$ & $(0.002)$ & $(0.002)$ & $(0.002)$ & $(0.002)$ \\
\hline & [0.002] & {$[0.001]$} & [0.002] & {$[0.002]$} & {$[0.002]$} & {$[0.002]$} & {$[0.001]$} & {$[0.001]$} & {$[0.002]$} & {$[0.001]$} \\
\hline \multirow[t]{3}{*}{$M I_{i, t}$} & $-0.76^{* * *}$ & $-0.71 * * *$ & $-0.80 * * *$ & $-0.93 * * *$ & $-0.73 * * *$ & $-0.84 * * *$ & $-0.71 * * *$ & $-0.70 * * *$ & $-0.83 * * *$ & $-0.98 * * *$ \\
\hline & $(0.12)$ & $(0.14)$ & $(0.12)$ & (0.12) & $(0.12)$ & $(0.12)$ & $(0.12)$ & $(0.12)$ & $(0.12)$ & $(0.13)$ \\
\hline & [0.25] & [0.39] & [0.27] & [0.27] & {$[0.26]$} & {$[0.26]$} & {$[0.25]$} & {$[0.25]$} & {$[0.26]$} & {$[0.30]$} \\
\hline \multirow[t]{3}{*}{$R I R_{i, t}$} & $-0.05 * * *$ & $-0.04 * * *$ & $-0.05 * * *$ & $-0.06 * * *$ & $-0.06 * * *$ & $-0.06 * * *$ & $-0.04 *$ & $-0.03 * *$ & $-0.06 * * *$ & $-0.03 * *$ \\
\hline & $(0.01)$ & $(0.01)$ & $(0.01)$ & $(0.01)$ & $(0.01)$ & $(0.01)$ & $(0.01)$ & $(0.01)$ & $(0.01)$ & $(0.01)$ \\
\hline & [0.02] & [0.02] & [0.02] & [0.02] & [0.03] & [0.02] & [0.02] & {$[0.02]$} & [0.02] & [0.02] \\
\hline \multirow{3}{*}{$R I R_{i, t} * C P V_{i, t}$} & $-0.002 * * *$ & $-0.004 * *$ & $-0.0008 *$ & $-0.003 * *$ & -0.0006 & $-0.0006^{* * *}$ & $-0.00007 * * *$ & $-0.0003 * * *$ & $-0.02 * * *$ & $-0.002 * *$ \\
\hline & $(0.0006)$ & $(0.001)$ & $(0.0004)$ & $(0.001)$ & $(0.0007)$ & $(0.0002)$ & $(0.00001)$ & $(0.00001)$ & $(0.006)$ & $(0.0007)$ \\
\hline & {$[0.001]$} & {$[0.002]$} & {$[0.0007]$} & {$[0.002]$} & {$[0.0007]$} & {$[0.0004]$} & {$[0.00003]$} & {$[0.00001]$} & {$[0.01]$} & {$[0.001]$} \\
\hline $\mathrm{R}_{2}$ & 0.47 & 0.40 & 0.44 & 0.43 & 0.45 & 0.44 & 0.48 & 0.47 & 0.44 & 0.41 \\
\hline Periods & 38 & 32 & 38 & 38 & 38 & 38 & 38 & 38 & 38 & 26 \\
\hline Countries & 108 & 106 & 108 & 108 & 108 & 108 & 108 & 108 & 108 & 108 \\
\hline Observations & 2057 & 1531 & 2057 & 2057 & 2057 & 2057 & 2057 & 2057 & 2057 & 1937 \\
\hline
\end{tabular}

Note: Standard errors are presented below the corresponding coefficients in brackets. The asterisks $* * * * *$ and $*$ indicate the significance at the 1,5 and 10 percent level, respectively. Cluster standard errors are presented in square brackets. 
Table 4: Determinants of fiscal balance (commodity-exporting countries)

\begin{tabular}{|c|c|c|c|c|c|c|c|c|c|c|}
\hline \multirow{5}{*}{$F B_{i, t-1}$} & \multicolumn{10}{|c|}{ Dependent variable: $F B_{i, t}$} \\
\hline & Crude oil & Steel & Soybean & Iron ore & Maize & Gold & Copper & Aluminium & Silver & Gas \\
\hline & $0.55 * * *$ & $0.39 * * *$ & $0.51 * * *$ & $0.46^{* * *}$ & $0.52 * * *$ & $0.50 * * *$ & $0.56 * * *$ & $0.57 * * *$ & $0.51 * * *$ & $0.53 * * *$ \\
\hline & $(0.03)$ & $(0.04)$ & $(0.03)$ & $(0.03)$ & $(0.03)$ & $(0.03)$ & $(0.03)$ & $(0.03)$ & $(0.03)$ & $(0.03)$ \\
\hline & {$[0.08]$} & {$[0.09]$} & [0.09] & [0.11] & {$[0.09]$} & [0.09] & {$[0.08]$} & [0.08] & [0.09] & {$[0.08]$} \\
\hline \multirow{3}{*}{$C P V_{i, t}$} & $-0.03 * * *$ & $-0.12 * * *$ & $-0.03 * * *$ & $-0.13 * * *$ & $-0.02 * *$ & $-0.01 * * *$ & -0.0003 & -0.0008 & $-0.47 * * *$ & 0.001 \\
\hline & $(0.009)$ & $(0.03)$ & $(0.008)$ & $(0.02)$ & $(0.01)$ & $(0.003)$ & $(0.0003)$ & $(0.001)$ & $(0.10)$ & $(0.01)$ \\
\hline & {$[0.01]$} & {$[0.03]$} & {$[0.01]$} & {$[0.05]$} & {$[0.01]$} & {$[0.008]$} & {$[0.0003]$} & [0.0009] & {$[0.20]$} & [0.01] \\
\hline \multirow{3}{*}{$P C C P_{i, t}$} & $0.03 * * *$ & $0.03 * * *$ & $0.02 * * *$ & 0.004 & $0.02 * * *$ & $0.02 * * *$ & $0.03 * * *$ & $0.03 * * *$ & $0.02 * * *$ & $0.03 * * *$ \\
\hline & $(0.004)$ & $(0.006)$ & $(0.007)$ & $(0.003)$ & $(0.005)$ & $(0.008)$ & $(0.005)$ & $(0.006)$ & $(0.004)$ & $(0.004)$ \\
\hline & {$[0.005]$} & {$[0.006]$} & [0.006] & {$[0.003]$} & {$[0.003]$} & [0.009] & {$[0.005]$} & {$[0.007]$} & {$[0.004]$} & {$[0.004]$} \\
\hline \multirow[t]{3}{*}{$C A P_{i, t}$} & 0.0007 & 0.001 & 0.002 & 0.002 & 0.003 & 0.002 & 0.0009 & 0.001 & 0.002 & 0.001 \\
\hline & $(0.002)$ & $(0.002)$ & $(0.002)$ & $(0.002)$ & $(0.002)$ & $(0.002)$ & $(0.002)$ & $(0.002)$ & $(0.002)$ & $(0.002)$ \\
\hline & [0.001] & [0.001] & {$[0.001]$} & [0.001] & [0.001] & [0.001] & [0.001] & {$[0.001]$} & {$[0.001]$} & {$[0.001]$} \\
\hline \multirow[t]{3}{*}{$M I_{i, t}$} & $-0.90 * * *$ & $-0.75 * * *$ & $-0.90 * * *$ & $-1.11 * * *$ & $-0.84 * * *$ & $-1.00 * * *$ & $-0.83 * * *$ & $-0.80 * * *$ & $-1.01 * * *$ & $-0.95 * * *$ \\
\hline & $(0.18)$ & $(0.24)$ & (0.19) & $(0.19)$ & $(0.19)$ & $(0.19)$ & (0.19) & (0.19) & (0.19) & $(0.20)$ \\
\hline & [0.26] & [0.22] & [0.29] & [0.26] & [0.28] & [0.27] & [0.27] & {$[0.27]$} & [0.27] & {$[0.32]$} \\
\hline \multirow[t]{3}{*}{$R I R_{i, t}$} & $-0.04 * * *$ & $-0.04 * * *$ & $-0.06 * * *$ & $-0.07 * * *$ & $-0.07 * * *$ & $-0.06 * * *$ & $-0.04 * *$ & -0.02 & $-0.07 * * *$ & -0.005 \\
\hline & $(0.02)$ & $(0.02)$ & $(0.02)$ & $(0.01)$ & $(0.02)$ & $(0.02)$ & $(0.02)$ & $(0.02)$ & $(0.02)$ & $(0.02)$ \\
\hline & [0.03] & [0.02] & [0.03] & [0.03] & [0.03] & {$[0.03]$} & {$[0.02]$} & [0.02] & {$[0.03]$} & [0.02] \\
\hline \multirow{3}{*}{$R I R_{i, t} * C P V_{i, t}$} & $-0.002 * *$ & $-0.005^{* *}$ & -0.0007 & -0.001 & 0.0002 & -0.0004 & $-0.00009 * * *$ & $-0.0004 * * *$ & -0.01 & $-0.003 * *$ \\
\hline & $(0.0009)$ & $(0.002)$ & $(0.0007)$ & $(0.002)$ & $(0.001)$ & $(0.0003)$ & $(0.00003)$ & $(0.0001)$ & $(0.009)$ & $(0.001)$ \\
\hline & {$[0.001]$} & {$[0.003]$} & {$[0.001]$} & {$[0.005]$} & {$[0.0007]$} & {$[0.0008]$} & [0.00004] & {$[0.0001]$} & {$[0.02]$} & {$[0.002]$} \\
\hline $\mathrm{R}_{2}$ & 0.49 & 0.43 & 0.46 & 0.45 & 0.47 & 0.46 & 0.50 & 0.49 & 0.46 & 0.48 \\
\hline Periods & 36 & 30 & 36 & 36 & 36 & 36 & 36 & 36 & 36 & 26 \\
\hline Countries & 45 & 44 & 45 & 45 & 45 & 45 & 45 & 45 & 45 & 45 \\
\hline Observations & 839 & 617 & 839 & 839 & 839 & 839 & 839 & 839 & 839 & 806 \\
\hline
\end{tabular}

Note: Standard errors are presented below the corresponding coefficients in brackets. The asterisks $* * *$, ** and * indicate the significance at the 1 , 5 and 10 percent level, respectively. Cluster standard errors are presented in square brackets. 
Table 5: Determinants of fiscal balance (commodity-importing countries)

\begin{tabular}{|c|c|c|c|c|c|c|c|c|c|c|}
\hline \multirow{5}{*}{$F B_{i, t-1}$} & \multicolumn{10}{|c|}{ Dependent variable: $F B_{i, t}$} \\
\hline & Crude oil & Steel & Soybean & Iron ore & Maize & Gold & Copper & Aluminium & Silver & Gas \\
\hline & $0.56^{* * *}$ & $0.50 * * *$ & $0.55 * * *$ & $0.54 * * *$ & $0.55 * * *$ & $0.55 * * *$ & $0.57 * * *$ & $0.57 * * *$ & $0.55 * * *$ & $0.51 * * *$ \\
\hline & $(0.02)$ & $(0.03)$ & $(0.02)$ & $(0.02)$ & $(0.02)$ & $(0.02)$ & $(0.02)$ & $(0.02)$ & $(0.02)$ & $(0.02)$ \\
\hline & {$[0.03]$} & [0.04] & {$[0.03]$} & {$[0.03]$} & {$[0.03]$} & {$[0.03]$} & {$[0.03]$} & {$[0.03]$} & {$[0.03]$} & {$[0.04]$} \\
\hline \multirow[t]{3}{*}{$C P V_{i, t}$} & -0.01 & $-0.08 * * *$ & $-0.01 *$ & $-0.05 * * *$ & 0.002 & -0.005 & 0.00001 & 0.0009 & -0.12 & 0.006 \\
\hline & $(0.007)$ & $(0.03)$ & $(0.007)$ & $(0.02)$ & $(0.01)$ & $(0.003)$ & $(0.0002)$ & $(0.001)$ & $(0.09)$ & $(0.01)$ \\
\hline & {$[0.008]$} & {$[0.03]$} & {$[0.008]$} & {$[0.02]$} & {$[0.01]$} & {$[0.003]$} & {$[0.0003]$} & {$[0.002]$} & [0.09] & {$[0.02]$} \\
\hline \multirow[t]{3}{*}{$P C C P_{i, t}$} & $0.02 * * *$ & $0.03 * * *$ & $0.01 *$ & 0.004 & $0.01 * *$ & 0.01 & $0.03 * * *$ & $0.03 * * *$ & $0.01 * *$ & $0.02 * * *$ \\
\hline & $(0.004)$ & $(0.007)$ & $(0.006)$ & $(0.003)$ & $(0.005)$ & $(0.007)$ & $(0.005)$ & $(0.006)$ & $(0.004)$ & $(0.004)$ \\
\hline & {$[0.006]$} & {$[0.006]$} & {$[0.008]$} & {$[0.003]$} & [0.004] & {$[0.007]$} & {$[0.006]$} & {$[0.005]$} & {$[0.003]$} & {$[0.005]$} \\
\hline \multirow{3}{*}{$C A P_{i, t}$} & 0.008 & 0.004 & 0.01 & 0.008 & 0.009 & 0.009 & 0.007 & 0.008 & 0.009 & 0.009 \\
\hline & $(0.006)$ & $(0.007)$ & $(0.006)$ & $(0.006)$ & $(0.006)$ & $(0.006)$ & $(0.006)$ & $(0.006)$ & $(0.006)$ & $(0.006)$ \\
\hline & {$[0.006]$} & {$[0.006]$} & {$[0.006]$} & {$[0.006]$} & {$[0.007]$} & [0.007] & {$[0.006]$} & {$[0.006]$} & {$[0.007]$} & {$[0.005]$} \\
\hline \multirow[t]{3}{*}{$M I_{i, t}$} & $-0.69 * * *$ & $-0.68 * * *$ & $-0.76 * * *$ & $-0.84 * * *$ & $-0.68 * * *$ & $-0.77 * * *$ & $-0.65 * * *$ & $-0.65 * * *$ & $-0.74 * * *$ & $-0.99 * * *$ \\
\hline & $(0.15)$ & $(0.18)$ & $(0.16)$ & $(0.16)$ & $(0.16)$ & $(0.16)$ & $(0.15)$ & $(0.15)$ & $(0.16)$ & $(0.17)$ \\
\hline & [0.35] & [0.53] & [0.37] & [0.38] & [0.36] & [0.37] & {$[0.35]$} & [0.35] & [0.36] & [0.42] \\
\hline \multirow{3}{*}{$R I R_{i, t}$} & $-0.05 * * *$ & $-0.04 * *$ & $-0.05 * *$ & $-0.06 * * *$ & $-0.06 * * *$ & $-0.05^{* * *}$ & $-0.04 * *$ & $-0.04 * *$ & $-0.05 * * *$ & $-0.05 * * *$ \\
\hline & $(0.02)$ & $(0.02)$ & $(0.02)$ & $(0.02)$ & $(0.02)$ & $(0.02)$ & $(0.02)$ & $(0.02)$ & $(0.02)$ & $(0.02)$ \\
\hline & [0.03] & {$[0.03]$} & [0.04] & [0.04] & {$[0.04]$} & {$[0.04]$} & [0.03] & [0.03] & {$[0.03]$} & [0.03] \\
\hline \multirow{3}{*}{$R I R_{i, t}{ }^{*} C P V_{i, t}$} & $-0.001 *$ & $-0.003^{*}$ & -0.0009 & $-0.003 * *$ & -0.001 & $-0.0007 * *$ & -0.00006 & $-0.0002 * *$ & $-0.02 * *$ & -0.001 \\
\hline & $(0.0007)$ & $(0.002)$ & $(0.0006)$ & $(0.001)$ & $(0.0009)$ & $(0.0003)$ & $(0.00002)$ & $(0.00009)$ & $(0.008)$ & $(0.0009)$ \\
\hline & {$[0.001]$} & [0.002] & {$[0.0008]$} & {$[0.002]$} & {$[0.001]$} & [0.0004] & {$[0.0003]$} & {$[0.0002]$} & {$[0.01]$} & {$[0.002]$} \\
\hline $\mathrm{R}_{2}$ & 0.46 & 0.39 & 0.44 & 0.43 & 0.44 & 0.44 & 0.47 & 0.46 & 0.44 & 0.37 \\
\hline Periods & 38 & 38 & 38 & 38 & 38 & 38 & 38 & 38 & 38 & 26 \\
\hline Countries & 63 & 63 & 63 & 63 & 63 & 63 & 63 & 63 & 63 & 63 \\
\hline Observations & 1218 & 1218 & 1218 & 1218 & 1218 & 1218 & 1218 & 1218 & 1218 & 1131 \\
\hline
\end{tabular}

Note: Standard errors are presented below the corresponding coefficients in brackets. The asterisks $* * *$, ** and * indicate the significance at the 1 , 5 and 10 percent level, respectively. Cluster standard errors are presented in square brackets. 
Table 6: Determinants of fiscal balance with one-step system-GMM

\begin{tabular}{|c|c|c|c|}
\hline & \multicolumn{3}{|c|}{ Dependent variable: $F B_{i, t}$} \\
\hline & $\begin{array}{l}\text { Full sample } \\
\text { (1) }\end{array}$ & $\begin{array}{c}\text { Commodity- } \\
\text { exporting } \\
\text { (2) }\end{array}$ & $\begin{array}{l}\text { Commodity- } \\
\text { importing } \\
\text { (3) }\end{array}$ \\
\hline \multirow[t]{2}{*}{$F B_{i, t-1}$} & $0.64 * * *$ & $0.64 * * *$ & $0.61 * * *$ \\
\hline & $(0.05)$ & $(0.102)$ & $(0.04)$ \\
\hline \multirow[t]{2}{*}{$C P V_{i, t}$} & $-0.04 * * *$ & $-0.07 * * *$ & -0.02 \\
\hline & $(0.02)$ & $(0.02)$ & $(0.02)$ \\
\hline \multirow[t]{2}{*}{$P C C P_{i, t}$} & $0.04 * * *$ & $0.05 * * *$ & $0.04 * * *$ \\
\hline & $(0.006)$ & $(0.008)$ & $(0.01)$ \\
\hline \multirow[t]{2}{*}{$C A P_{i, t}$} & 0.001 & 0.0009 & 0.005 \\
\hline & $(0.0012)$ & $(0.001)$ & $(0.006)$ \\
\hline \multirow[t]{2}{*}{$M I_{i, t}$} & $-0.32 * * *$ & $-0.4 * * *$ & $-0.28 * *$ \\
\hline & $(0.09)$ & $(0.14)$ & $(0.11)$ \\
\hline \multirow[t]{2}{*}{$R I R_{i, t}$} & $-0.03 *$ & $-0.03 \Phi$ & -0.03 \\
\hline & $(0.02)$ & $(0.02)$ & $(0.02)$ \\
\hline \multirow[t]{2}{*}{$R I R_{i, t} * C P V_{i, t}$} & $-0.004 *$ & $-0.004 \Phi$ & $-0.003 \Phi$ \\
\hline & $(0.002)$ & $(0.003)$ & $(0.002)$ \\
\hline AR (1) p-value & 0.00 & 0.01 & 0.00 \\
\hline AR (2) p-value & 0.28 & 0.68 & 0.34 \\
\hline Hansen p-value & 0.20 & 0.42 & 0.18 \\
\hline Instruments & 44 & 44 & 44 \\
\hline
\end{tabular}

Note: Standard errors are presented below the corresponding coefficients in brackets. The asterisks ***, ** and * indicate the significance at the 1, 5 and 10 percent level, respectively. $\Phi$ indicates the significance at the 20 percent level. 
Figure 1: Commodity price volatility

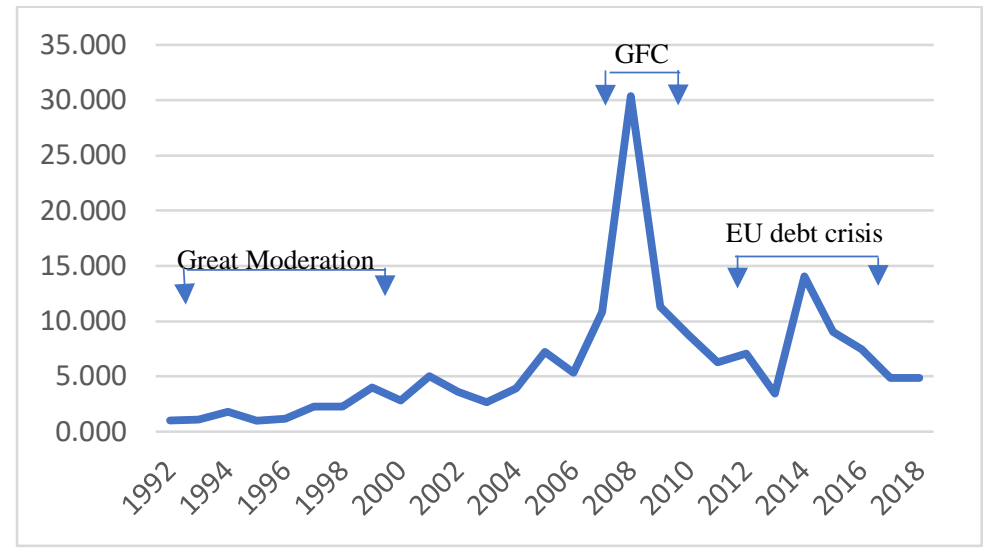

Source: Author's calculation based on IMF (2019)

Figure 2a: Marginal effect of commodity price volatility on fiscal balance (full sample)

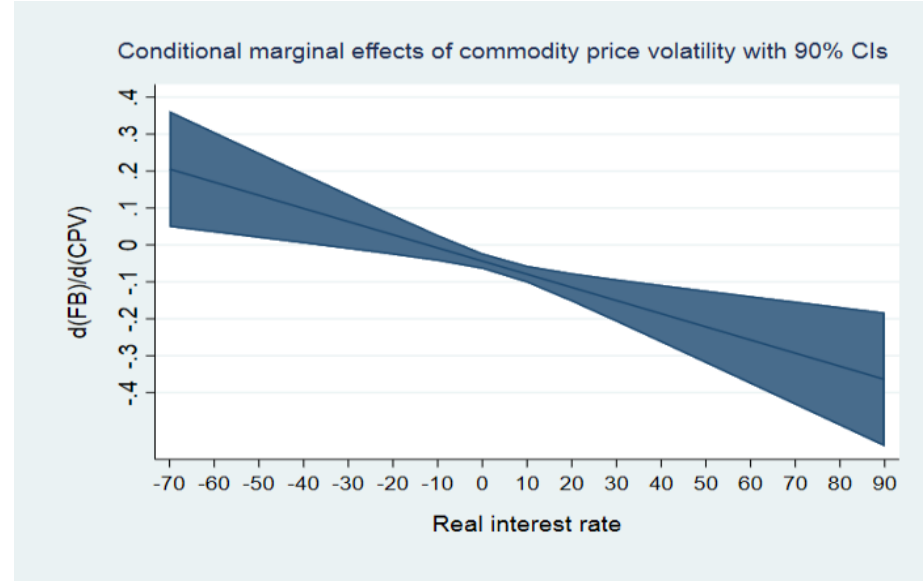

Figure 2b: Marginal effect of commodity price volatility on fiscal balance (commodity-exporting)

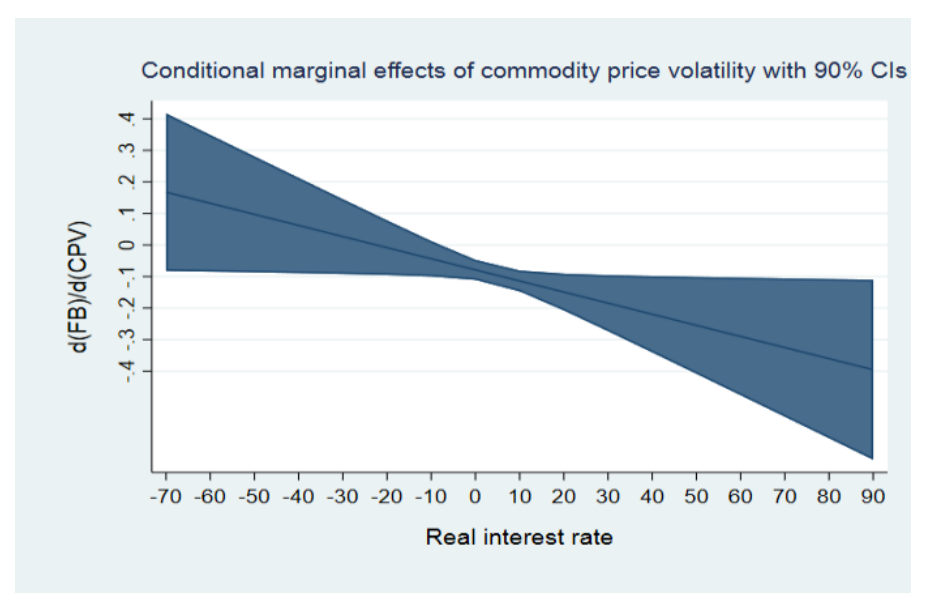


Figure 2c: Marginal effect of commodity price volatility on fiscal balance (commodityimporting)

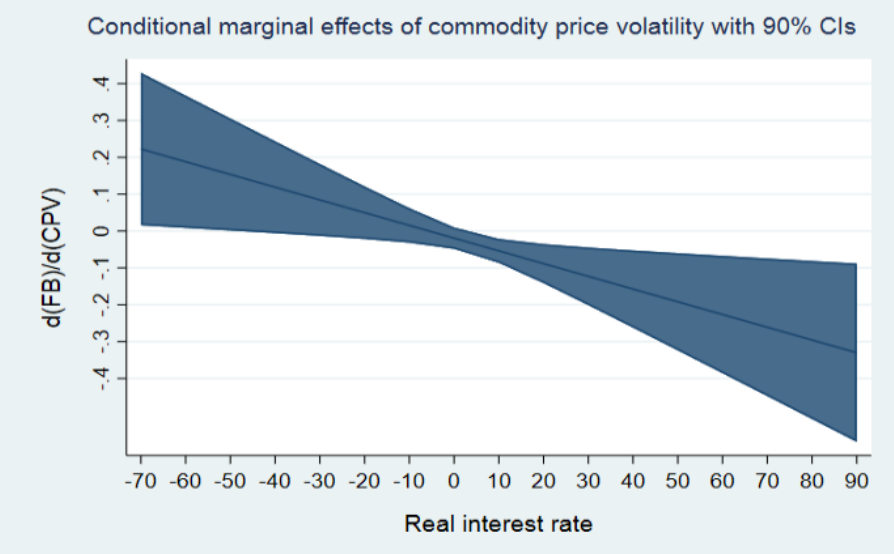

\section{Appendix A}

Table A1: List of countries $(\mathrm{n}=108)$

\begin{tabular}{llll}
\hline Albania & Cote d'Ivoire & Liberia & Qatar \\
Algeria & Croatia & Macedonia, FYR & Romania \\
Angola & Czech Rep. & Madagascar & Russian Federation \\
Argentina & Dominican Republic & Malawi & Rwanda \\
Armenia & Egypt, Arab Rep. & Malaysia & Senegal \\
Australia & The Gambia & Mali & Serbia \\
Azerbaijan & Georgia & Malta & Seychelles \\
Bahrain & Guatemala & Mauritia & Sierra Leone \\
Bangladesh & Guinea & Mauritius & South Africa \\
Belarus & Haiti & Mexico & South Sudan \\
Belize & Honduras & Moldova & Sri Lanka \\
Benin & Hungary & Mongolia & Swaziland \\
Bolivia & India & Montenegro & Sweden \\
Bosnia and Herzegovina & Indonesia & Mozambique & Switzerland \\
Botswana & Iran & Namibia & Tajikistan \\
Brazil & Israel & Netherlands & Tanzania \\
Brunei Darussalam & Italy & New Zealand's & Thailand \\
Bulgaria & Jamaica & Nicaragua & Timor \\
Burkina Faso & Japan & Niger & Togo \\
Burundi & Jordan & Nigeria & Uganda \\
Cabo Verde & Kenya & Oman & Ukraine \\
Canada & Korea & Pakistan & UK \\
Chile & Kuwait & Panama & USA \\
China & Kyrgyz & Papua New & Uruguay \\
Colombia & Lao PDR & Paraguay & Venezuela \\
Congo, Dem. Rep & Lebanon & Peru & Vietnam \\
Costa Rica & Lesotho & Philippines & Zimbabwe \\
\hline & & &
\end{tabular}


Table A2: List of commodity-exporting and commodity-importing countries

\begin{tabular}{ll|ll}
\hline \multicolumn{2}{l|}{ Commodity-exporting $(\mathrm{n}=45)$} & Commodity-importing $(\mathrm{n}=63)$ \\
\hline Algeria & Paraguay & Albania & Lesotho \\
Argentina & Peru & Angola & Liberia \\
Armenia & Russian Federation & Azerbaijan & Macedonia, FYR \\
Australia & Rwanda & Bangladesh & Madagascar \\
Bahrain & Senegal & Belarus & Malaysia \\
Benin & Sierra Leone & Belize & Malta \\
Bolivia & Tajikistan & Bosnia and Herzegovina & Mauritius \\
Botswana & Tanzania & Brazil & Mexico \\
Burundi & Togo & Brunei Darussalam & Mongolia \\
Chile & Uganda & Bulgaria & Montenegro \\
Colombia & Uruguay & Burkina Faso & Netherlands \\
Cote d'Ivoire & Venezuela & Cabo Verde & Nigeria \\
Egypt, Arab Rep & Zimbabwe & Canada & Oman \\
The Gambia & & China & Pakistan \\
Guatemala & & Congo, Dem. Rep & Philippines \\
Honduras & Costa Rica & Qatar \\
Indonesia & & Croatia & Romania \\
Iran & Czech Rep. & Serbia \\
Kenya & Dominican Republic & Seychelles \\
Korea & Georgia & South Africa \\
Kyrgyz Republic & & Guinea & South Sudan \\
Malawi & & Haiti & Sri Lanka \\
Mali & & Hungary & Swaziland \\
Mauritia & India & Sweden \\
Moldova & Israel & Switzerland \\
Mozambique & & Italy & Thailand \\
Namibia & & Jamaica & Timor \\
New Zealand's & & Japan & Ukraine \\
Nicaragua & Jordan & UK \\
Niger & Kuwait & USA \\
Panama & Lao PDR & Vietnam \\
Papua New & Lebanon & \\
\hline
\end{tabular}


Table A3: Description of the variables

\begin{tabular}{|c|c|c|c|}
\hline Variables & Mnemonic & Description & Source \\
\hline \multicolumn{4}{|l|}{ Dependent variable } \\
\hline $\begin{array}{l}\text { Fiscal balance } \\
\text { (percent of GDP) }\end{array}$ & $F B_{i, t}$ & $\begin{array}{l}\text { Primary net lending/borrowing is net } \\
\text { lending }(+) / \text { borrowing }(-) \text { plus net interest } \\
\text { payable/paid. }\end{array}$ & WEO, IMF \\
\hline \multicolumn{4}{|l|}{ Control variables } \\
\hline Commodity prices & $C P_{i, t}$ & $\begin{array}{l}\text { All commodity price index using } 2016=100 \\
\text { includes both fuel and non-fuel price indices. }\end{array}$ & $\begin{array}{l}\text { Commodity } \\
\text { data portal, } \\
\text { IMF }\end{array}$ \\
\hline $\begin{array}{l}\text { Commodity price } \\
\text { volatility }\end{array}$ & $C P V_{i, t}$ & Use standard deviation to estimate volatility. & $\begin{array}{l}\text { Author's } \\
\text { calculation }\end{array}$ \\
\hline $\begin{array}{l}\text { Gross } \\
\text { formation } \\
\text { growth) }\end{array}$ & $C A P_{i, t}$ & $\begin{array}{l}\text { Annual growth rate of gross capital formation } \\
\text { based on constant } 2010 \text { U.S. Gross capital } \\
\text { formation consists of outlays on additions to the } \\
\text { fixed assets of the economy plus net changes in the } \\
\text { level of inventories. }\end{array}$ & WDI, WB \\
\hline $\begin{array}{l}\text { Military expenditure } \\
\text { (percent of GDP) }\end{array}$ & $M I_{i, t}$ & $\begin{array}{l}\text { Military expenditures data from SIPRI are derived } \\
\text { from the NATO definition, which includes all } \\
\text { expenses. }\end{array}$ & WDI, WB \\
\hline $\begin{array}{l}\text { Real interest rate } \\
\text { (percent) }\end{array}$ & $R I R_{i, t}$ & $\begin{array}{l}\text { Real interest rate is the lending interest rate } \\
\text { adjusted for inflation as measured by the GDP } \\
\text { deflator. }\end{array}$ & WDI, WB \\
\hline $\begin{array}{l}\text { Individual commoditie } \\
\text { crude oil, still, iron } \\
\text { ore, soybean, maize, } \\
\text { gold, copper, silver, } \\
\text { aluminium and gas }\end{array}$ & & All commodity price index using $2016=100$. & $\begin{array}{l}\text { Commodity } \\
\text { data portal, } \\
\text { IMF }\end{array}$ \\
\hline
\end{tabular}

Note: We use percentage change to obtain the data in stationary in commodity prices series and expressed as $P C C P_{i, t}$ in equation 1.

Fiscal balance $\left(\boldsymbol{F} \boldsymbol{B}_{i, t}\right)$ : A wide variety of fiscal measures is available, including deficits and debts, and nominal or cyclically adjusted data. Fiscal balance is a sound representation of the government's fiscal policy because governments express annual targets as a flow term (e.g., balance or deficit), not in a static term, such as debt (Tujula \& Wolswijk 2004).

Lagged Fiscal balance $\left(\boldsymbol{F} \boldsymbol{B}_{\boldsymbol{i}, \boldsymbol{t}-1}\right)$ : We include the lagged fiscal balance as an influencing variable to correct past budgetary imbalances. A significant change in budget deficits in the past may induce governments to absorb part of the recent increases. Changes in fiscal balance may also result from budgetary inertia, meaning that previous fiscal policy decisions, such as 
the implementation of tax reforms and significant spending reforms, can affect public finances in the following years.

Commodity price volatility $\left(\boldsymbol{C P} \boldsymbol{V}_{\boldsymbol{i}, t}\right)$ : According to Prebisch (1962), and Cuddington et al (2002) others, primary commodity prices are more volatile than those of manufactured goods and services. In particular, after the recent GFC in 2007-2009, commodity price volatility increased considerably (Omojolaibi \& Egwaikhide 2014). As a result, government revenue tends to be more volatile — along with government spending and the fiscal balance.

Percentage change in commodity prices $\left(\boldsymbol{P C C P} \boldsymbol{P}_{i, t}\right)$ : It is expected that commodity prices positively affect fiscal balance in commodity-exporting countries because government finance is heavily dependent on the revenue of primary commodity exports. During boom periods, tax formulae dictate that profits are subject to higher marginal tax rates. Similarly, during difficult times, government may lower the tax burden on the natural resource sector. A commodityimporting country's fiscal balance is also influenced by the commodity prices through the trade $\operatorname{tax}$.

Capital growth $\left(\boldsymbol{C A P} \boldsymbol{P}_{i, t}\right)$ : Capital formation is an important element of fiscal balance. Capital growth improves economic growth and prosperity (Milesi-Ferretti \& Moriyama 2006), which increase investment and employment in the economy. Fiscal balance improves with rising tax revenues and decreased government expenditure on social benefits. Eventually, government fiscal balance improves with the increased capital growth.

Military expense $\left(\boldsymbol{L} \boldsymbol{M}_{\boldsymbol{i}, \boldsymbol{t}}\right)$ : According to Cappelen et al (1984), increased military expenditure reduces economic growth. As this expenditure increases, so does total government expenditure, leading to higher tax rates in the private sector, which ultimately reduce private investment and eventually decrease the fiscal balance.

Real interest rate $\left(\boldsymbol{R I} \boldsymbol{R}_{\boldsymbol{i}, t}\right)$ : A higher real interest rate causes lower investment in the economy that leads to a lower government tax revenue and eventually lower fiscal balance. According to the Comley et al (2002) high real interest rate decrease the capital stock that causes lower output and investment. Therefore, it is expected a negative relationship between fiscal balance and higher real interest rate. 
Table A4: Descriptive statistics

Mean

\begin{tabular}{ccrrrrr}
\hline$F B_{i, t}$ & \multicolumn{1}{c}{$C P V_{i, t}$} & \multicolumn{1}{c}{$C P_{i, t}$} & \multicolumn{1}{c}{$P C C P_{i, t}$} & \multicolumn{1}{c}{$C A P_{i, t}$} & $M I_{i, t}$ & \multicolumn{1}{c}{$R I R_{i, t}$} \\
\hline-0.56 & 7.25 & 110.02 & 1.83 & 7.36 & 1.95 & 6.74 \\
-0.61 & 5.31 & 113.57 & 6.17 & 5.25 & 1.58 & 5.52 \\
36.01 & 30.37 & 182.70 & 20.84 & 744.86 & 12.06 & 93.91 \\
-35.06 & 0.99 & 48.04 & -46.81 & -164.50 & 0.00 & -69.53 \\
4.60 & 6.20 & 44.18 & 18.38 & 31.21 & 1.48 & 10.34 \\
0.33 & 2.45 & 0.11 & -1.22 & 11.96 & 2.21 & 1.06 \\
13.03 & 9.66 & 1.68 & 3.95 & 248.23 & 10.68 & 13.85 \\
1964 & 1964 & 1964 & 1964 & 1964 & 1964 & 1964
\end{tabular}

Note: $F B_{i, t}=$ Fiscal balance, $C P V_{i, t}=$ Commodity price volatility, $C P_{i, t}=$ Commodity prices, $P C C P_{i, t}=$ Percentage change in commodity prices, $C A P_{i, t}=$ Capital growth and $R I R_{i, t}=$ Real interest rate.

Table A5: Unit root test

\begin{tabular}{ccc|cc} 
& \multicolumn{2}{l|}{ Augmented Ducky-Fuller (ADF) } & \multicolumn{2}{l}{ Phillips-Peron (PP) } \\
\cline { 2 - 5 } & Statistics & $p$-value & Statistics & $p$-value \\
\cline { 2 - 5 }$F B_{i, t}$ & 435.61 & 0.00 & 527.65 & 0.00 \\
$C P V_{i, t}$ & 414.06 & 0.00 & 680.72 & 0.00 \\
$C P_{i, t}$ & 105.14 & 1.00 & 99.09 & 1.00 \\
$P C C P_{i, t}$ & 935.95 & 0.00 & 1334.24 & 0.00 \\
$C A P_{i, t}$ & 905.87 & 0.00 & 1543.85 & 0.00 \\
$M I_{i, t}$ & 445.25 & 0.00 & 697.73 & 0.00 \\
$R I R_{i, t}$ & 687.86 & 0.00 & 1037.70 & 0.00 \\
\hline
\end{tabular}

Note: $F B_{i, t}=$ Fiscal balance, $C P V_{i, t}=$ Commodity price volatility, $C P_{i, t}=$ Commodity prices, $P C C P_{i, t}=$ Percentage change in commodity prices, $C A P_{i, t}=$ Capital growth and $R I R_{i, t}=$ Real interest rate.

Table A6: Results of the Hausman test

\begin{tabular}{llll}
\hline \multicolumn{2}{l}{ Null hypothesis: RE model is appropriate } & & \\
\hline Country groups & Chi-Sq. Statistics & $p$-value & Comments \\
\hline Full Sample & 243.97 & 0.00 & Reject Null hypothesis \\
Commodity-exporting countries & 90.85 & 0.00 & Reject Null hypothesis \\
Commodity-importing countries & 154.03 & 0.00 & Reject Null hypothesis \\
\hline
\end{tabular}




\section{Appendix B}

\section{B 1.1. pooled OLS model}

In the pooled OLS model, we have pooled all observations in OLS regression, meaning that, implicitly, we assume that the coefficient is the same for each individual country. Thus, the model (1) follows the form:

$$
\begin{aligned}
& F B_{i, t}=\beta_{0}+\beta_{1} F B_{i, t-1}+\beta_{2} C P V_{i, t}+\beta_{3} P C C P_{i, t}+\beta_{4} C A P_{i, t}+\beta_{5} M I_{i, t}+\beta_{6} R I R_{i, t} \\
& +\beta_{7} R I R_{i, t} * C P V_{i, t}+\varepsilon_{i, t}
\end{aligned}
$$

\section{B 1.2. Random effect (RE) model}

The rationale of the RE model is that, unlike the FE model, the variation between entities is assumed to be random and uncorrelated with the predictor or independent variables included in the model. For example, in the RE model, it is assumed that the unobserved effects (e.g., geographical factors, natural endowments, political and cultural systems) are not correlated with commodity prices or fiscal balance. The RE model includes all FE assumptions as well as an additional requirement that $\left(Q_{i}\right)$ is independent of all explanatory variables in all time periods. Hence, the variability of the constant for each section originates from:

$$
\beta_{0 i}=\beta_{0}+Q_{i}
$$

where $Q_{i}$ is a zero-mean standard random variable. Therefore, equation (1) with random effects takes the following form:

$$
\begin{aligned}
& F B_{i, t}=\beta_{0}+\beta_{1} F B_{i, t-1}+\beta_{2} C P V_{i, t}+\beta_{3} P C C P_{i, t}+\beta_{4} C A P_{i, t}+\Sigma_{i=0}^{n} \beta_{5} M I_{i, t}+\beta_{6} R I R_{i, t} \\
& +\beta_{7} R I R_{i, t} * C P V_{i, t}+Q_{i}+\varepsilon_{i, t}
\end{aligned}
$$

We estimate Equations 5 and 7 for all countries and commodity groups mentioned above. 